\section{B A Institute of \\ YK Business Administration \\ 六下 \\ Karachi \\ Leadership and Ideas for Tomorrow}

Business Review

Volume 15 Issue 1 January-June 2020

$1-1-2020$

\title{
Corporate governance and capital structure as driving force for financial performance: Evidence from non-financial listed companies in Pakistan
}

\author{
Zahid Bashir \\ University of Gujrat, Pakistan \\ Ghulam Ali Bhatti \\ University of Sargodha, Pakistan \\ Asad Javed \\ University of Gujrat, Pakistan
}

Follow this and additional works at: https://ir.iba.edu.pk/businessreview

Part of the Finance Commons, Management Sciences and Quantitative Methods Commons, and the Marketing Commons

\section{c) (i)}

This work is licensed under a Creative Commons Attribution 4.0 International License.

\section{Recommended Citation}

Bashir, Z., Bhatti, G. A., \& Javed, A. (2020). Corporate governance and capital structure as driving force for financial performance: Evidence from non-financial listed companies in Pakistan. Business Review, 15(1), 108-133. Retrieved from https://doi.org/10.54784/1990-6587.1013

This article is brought to you by iRepository for open access under the Creative Commons Attribution 4.0 License and is available at https://ir.iba.edu.pk/businessreview/vol15/iss1/14. For more information, please contact irepository@iba.edu.pk. 


\title{
Corporate governance and capital structure as driving force for financial performance: Evidence from non-financial listed companies in Pakistan
}

\author{
Zahid Bashir • Ghulam Ali Bhatti • \\ Asad Javed
}

\begin{abstract}
This research examines the intervention of capital structure with different characteristics of corporate governance and different measures of financial performance. Data was collected from 113 PSX listed firms ranging from 2013-2018. The study uses multiple regression approach for testing the required set of hypotheses. The results reveal that insider shareholding, and board size significantly but negatively affect financial performance whereas, audit committee's size positively, and significantly affects financial performance. Furthermore, about $20 \%$ of CEOs hold dual positions in listed firms, which also has a positive impact on financial performance. The results also reveal that capital structure positively influences financial performance. This research adds to the literature on corporate governance and firm performance in emerging countries, particularly Pakistan.
\end{abstract}

Keywords Corporate governance $\cdot$ Capital structure $\cdot$ Financial performance

\section{Introduction}

\subsection{Research background}

The practice of corporate governance gained momentum after the 19th century with the incidence of the financial crunch of 1998 in Asia, Brazil and Russia where poor and inefficient corporate behaviour had worsened the global financial situation and some self-delivered disgraces like Enron, Satyam Computers had further destabilized the world financial system. However, these are not the

\footnotetext{
Zahid Bashir

University of Gujrat-Pakistan

E-mail: zahid.bashir@uog.edu.pk

Ghulam Ali Bhatti

University of Sargodha-Pakistan

Asad Javed

University of Gujrat-Pakistan

(c)Bashir, Z., Bhatti, A. G. and Javed. A. 2020
} 
only causes as to why corporate governance has become a main anxiety for world-wide viable growth (Becht et al 2002). Another reason for corporate failure is agency conflicts. The conflict between the principal and the agent who represents the owner can arise due to non-alignment of their interests. Agency problem as this is called, states that the directors are not so careful about other's resources as for their own (Letza et al 2004). The principals want to increase their wealth whereas managers try to enhance their resources. So, a system is required to reduce these agency issues.

Corporate governance (CG) is an arrangement of productive and worthwhile supervision, direction and effective control for a corporation to reduce agency issues (Keasey and Wright 1993). Pillai and Al-Malkawi (2018) state that it allows control activities that provide owners with required information and holds management responsible for their actions. The basic aim of CG is to give a guarantee to principals that the management is working in the shareholder's interest(Jensen and Meckling 1976; Shleifer and Vishny 1997).

In Pakistan, the governance system and practices are mostly different from other developing nations (Yasser et al 2017). Pakistan is a common law country and has an Anglo-Saxon model. Most of the organizations have no separate supervisory board and supervision is mostly done within the organization coat. A Corporate Governance institute of Pakistan was established during 2004 for effective supremacy in this domain. The purpose of the establishment of the institute was to deliver awareness and information for better and effective governance practices to all stakeholders.

The capital structure (CS) of an organization refers to how an organization is funded by a variety of equity and debt resources. CS choice, as a few theories recommend, is among the critical decisions made by the directors. Financial leverage refers to the proportion of entire debts to total capital employed. Financial issues arising out of CS not only impact the performance of the company but also powerfully affect macroeconomic results. Therefore, for both managers and suppliers of credit the CS is of extreme significance.

Previous literature mainly considers the consequences of corporate governance as a factor on financial performance as an outcome (Hassan and Halbouni 2013; Malik and Makhdoom 2016; Pillai and Al-Malkawi 2018). However, previous studies showed contradictory outcomes and did not investigate the combined impact of capital structure and corporate governance on financial performance. Therefore, the impact of corporate governance on financial performance while controlling for capital structure needs to be investigated. This question is of vital importance because the detachment of possession and authority in a company may bring about management applying inefficient activities, enjoying perks, picking outputs that best satisfy their own inclinations, or generally neglecting to expand firm value. Consequently, the agency cost of external owners meets the lost incentive from proficient managers augmenting their own value. As opposed to firm's value, the corporate governance and capital structure decision may help to alleviate agency outlays.

Several studies prove that agency conflicts affect corporate governance, financial decision making and performance of a firm. Corporate governance increases the ability of an organization by improving supervision and control. Hence, it 


\section{Z. Bashir et. al}

plays an integral part in reducing agency problems (Shleifer and Vishny 1997). Good governance helps an organization to get more credit from financial institutions, builds straightforwardness and lessens organizational clashes whereas weakly governed firms confront more issues because the management of such firms can easily get private advantages.

\subsection{Research objectives}

This study attempts to analyse the interaction of capital structure with different characteristics of corporate governance and different measures of financial performance using Baron and Kenny (1986) four-step procedure on non-financial firms in the PSX. The specific objectives of this research are as follows:

1. To approximate the direct nexus of the dynamic characteristics of corporate governance with different indicators of performance of PSX listed nonfinancial firms.

2. To evaluate the direct nexus of the dynamic characteristics of corporate governance with the capital structure of PSX listed non-financial firms.

3. To assess the direct nexus of capital structure with different performance indicators of PSX listed non-financial firms.

4. To bear out the intermediation of capital structure for the nexus of the dynamic characteristics of corporate governance with different performance indicators of PSX listed non-financial firms.

\subsection{Research significance}

This study provides worthwhile information of utmost importance for academics, policymakers, and further interested-parties. The findings of this study will help the management and decision-makers/policymakers of non-financial institutions of Pakistan to mend the market as well as accounting-based performance by making use of the dynamic characteristics of corporate governance over and above the intermediation of capital structure.

This research study analyzes the prevailing literature of the dynamic characteristics of corporate governance with different performance indicators of PSX listed non-financial firms for an emergent country like Pakistan. According to the researcher's understanding, no such study so far has been piloted for the Pakistani non-financial industry.

The remaining part of this study is arranged as follows: In the second step an extensive survey of literature in relation to corporate governance, capital structure and financial performance has been conducted. This is followed by an explanation of the research methodology, results, discussion and conclusion.

\section{Literature review}

This section provides a detailed examination of studies with respect to corporate governance, capital structure and financial performance. It makes use of the 
agency theory and the free cash flow theory to develop a framework that relates the corporate governance factor and the capital structure factor with financial performance as an outcome.

\subsection{Theoretical underpinning}

The perspectives regarding corporate governance and capital structure are as follows:

a) Agency theory

Agency paradox has been conventionally associated with corporate governance. Agency theory or agency relationship arises when management operates the business on behalf of the investors. Agency theory indicates that managers are the representatives of investors and it is expected that they should work in the best interest of the principals, but the agents may not work accordingly. The interests of both the parties are often non aligned which ultimately leads to the agency problem (Jensen and Meckling 1976). Agency cost arises as a result of the agency problem and includes monitoring expenses by shareholders, bonding expenses by management and residual costs.

b) Free cash flow theory

Free cash flow (FCF) theory states that there is a potential interest of indebtedness which leads to detention of managerial vigilance. When an organization has an incredible sum of money accessible, it tends to contribute it on passive NPV ventures, or on the utilization of advantages to expanding the organization's size. Issuance of excessive debt subsequently increases the interest and the payment of loan reduces accessible free cash flow streams because debt indulges the management to pay-off cash flows. So, debt gives the privilege to money lenders to liquidate the firm if the firm fails to pay off its dues.

Jensen and Meckling (1976) specified that another conceivable issue that affects agency costs is risk movement. If a firm uses more debt, it's manager will hesitate to invest in risky projects which as a result may not generate the desired level of cash flows. Hence, the firm may not be able to pay the agreed interest to creditors on a specified date. It will also cause reduced profitability in that year and the firm may fail in distributing profits. Leverage may not only decrease agency cost of FCF but can also increase the competency of the managers.

\subsection{Factor-wise review}

\subsubsection{Corporate governance and financial performance}

Corporate governance includes an array of productive and worthwhile supervision activities that direct managerial decisions and aid in enhancing the organization's performance. It is an effective governance procedure that can reduce agency issues by aligning management and executives on the same page. Pillai and Al-Malkawi (2018) state that it performs control activities that provide owners their required information and holds management responsible for their

Business Review: (2020) 15(1):108-133 


\section{Z. Bashir et. al}

actions. The concept of corporate governance is used as an instrument to minimize agency skirmishes that may affect an organization's capital structure. It is fundamental for an organization to inculcate a culture of responsibility, cent percent disclosure, truthfulness and accountability which will increase shareholder's wealth and improve firm performance.

a) Institutional shareholding and financial performance

Institutional theorists argue that the environment of an organization powerfully affects the growth of formal buildings of the organization. Institutional shareholders are active members that oversee the organization. The institutional hypothesis identifies with the impact of those standards, values, convictions, legal and administrative frameworks on the firms' structure, conduct and basic leadership component. There are different points of view regarding the impact of institutional shareholdings on firm performance.

The "active monitoring hypothesis" says that institutional shareholders and firm value are positively linked and contends that organizations are furnished with assets, mastery and ability to screen administrations' state of mind and keep their self-serving conduct (Shleifer and Vishny 1997). The other institutional advantages are a reduction of principal-agent asymmetric information. As per the "passive monitoring" view, institutional investors are involved in short-term securities to get benefits based on symmetric information to fulfill their needs (Elyasiani and Jia 2010) instead of enhancing corporate governance and firm performance. Accordingly, no association or a weak association is anticipated between institutional shareholding and firm value.

b) Insider shareholding and financial performance

There are two inverse arguments to consider the impact of insider shareholding and firm performance i.e. convergence-of-interest proposition and entrenchment proposition (Jensen and Meckling 1976). According to the first proposition, executives and investors work on similar goals to get higher utility by aligning their interests (Donaldson and Davis 1991; Gu and Kim 2001). Conversely, the entrenchment proposition states that higher managerial shareholding may affect firm performance because it changes the conventional agent-principal issue to an issue including various principals with diverse objectives at the cost of minority shareholdings (Shleifer and Vishny 1997).

Agrawal and Knoeber (1996) documented that insider shareholding, external directors, debt policy and control activities of corporations affect firm performance. In addition to this, Pillai and Al-Malkawi (2018) state that corporate governance proxies such as small board size, non-duality and dividend payments significantly affect firm performance. However, leverage and institutional shareholding do not affect agency cost and performance of the firm. Chiang (2005) demonstrates statistically significant but negative relationship between director' ownership and FP. This infers the concurrence of convergence-of-interest and entrenchment assumption. Because at a certain point with the increase in insider shareholding firm performance also increases but after that firm performance shows a decreasing trend. Apart from these, Himmelberg et al (1999) and Chen et al (2016) show a weak relationship between director shareholdings and firm performance.

c) Board size and financial performance 
Board size refers to the number of executives on the board (Yeh and Trejos 2015). Resource dependency theory postulates that larger size of the board improves FP because of different skills, information, and technical knowledge of executives (Pfeffer and Salancik 1978). Board size assumes a critical part in executives' capacity to administer and control the management. Existing literature has shown contradictory results regarding the association of the size of the board with financial performance. Generally, the results recommend that the firm's performance decreases by increasing the size of the board. The likely cause for these results might be that a larger board size may lead to ineffective communication, decision making along with an ineffective management system. d) The concept of duality and financial performance CEO duality is a vital part of the corporate governance instrument for managing board structure (Baliga et al 1996). Several theories give different perspectives on CEO duality and the firms' performance relationship (Elsayed 2007; Guillet et al 2013; Krause et al 2014). Both the agency and resource dependence theory emphasize on the non-duality of the CEO because it can improve supervision of the board (Elsayed 2007). Several studies demonstrate positive association such as (Arora and Sharma 2016; Guillet et al 2013; Hassan and Halbouni 2013; Rechner and Dalton 1991). Conversely, CEO duality negatively affects the value of Malaysian firms (Haniffa and Hudaib 2006). Additionally, many other studies show a negative association such as (Baliga et al 1996; Elsayed 2007).

e) The audit committee's size and financial performance

The audit committee gives an extra shield against misrepresentation and guarantees that they meet all the essential guidelines and best practices. The audit committee must have required qualifications and capabilities to do their duties. An effective, trained and responsible audit committee decreases information asymmetry and enhances supervision and control of management (Aldamen et al 2012). Further, it is contended that companies that have more effective and capable audit committees have fewer chances of fraud and errors, thus reducing the probability of surprising bad performance. Subsequently, an optimistic relation was expected between the audit committee and financial performance. However, Aldamen et al 2012 indicate a negative relationship. El Mir and Seboui (2008) suggested that larger audit committees can create unproductive supremacy due to regular meetings, which ultimately increase expenses.

f) Top-20 shareholders and financial performance

Prior studies inspected that ownership concentration and FP are associated but indicate contradictory results. A study conducted by Darko et al (2016) revealed that ownership concentration and firm performance are positively linked. If ownership and controlling authorities are different, it creates opportunities for managers to increase their own resources instead of maximizing the shareholders' wealth. Conversely, if goals and interests of both the owners and the managers are the same and managers have share then ownership may enhance performance. So, controlling owners can have more opportunities to control management and maximize firm performance. Eventually, concentrated ownership control can decrease agency (Maury 2006). In short, agency problems are less in those companies that have concentrated ownership (Al-Najjar and Abed 2014).

Business Review: (2020) 15(1):108-133 


\section{Z. Bashir et. al}

Though, there are inconclusive results concerning the association between block holder ownership and FP (Heugens et al 2009; Hiraki et al 2003) find that ownership concentration and firm profitability are positively related and indicate how market worth is positively associated with increased share price detained by bigger investors.

g) Board independence and financial performance

The external directors play a vital role in the composition of the board (Barnhart and Rosenstein 1998). Numerous outside executives empower the board to be more autonomous and give a larger amount of corporate administration to investors by incorporating and planning the interior and outer premiums of different investors. However, (Hart 1995) states that due to lack of time, access to data and a firm's financial information, external directors may not perform well in decision making.

Prior literature indicates contradictory results about the impact of board independence on FP. The contradiction may occur due to constrained, inaccurate or absence of variables in the model that can affect FP, various institutional components and administrative practices in the market (Fan et al 2011). In addition to this, many other studies have shown that independence of the board and firm performance are linked in the case of US (Pearce and Zahra 1991) UK (Ezzamel and Watson 1993), New Zealand (Hossain et al 2001) and Korea (Joh and Jung 2012). Consequently, Dalton et al (1999) have indicated no association between board independence and FP. Similarly, Haniffa and Hudaib (2006) also demonstrate that in Malaysian firms board independence does not affect firm performance.

\subsubsection{Capital structure and financial performance}

The capital structure of a firm refers to how an organization is financed by a mixture of equity and debt capital. Capital structure choice, as a few theories recommend, is among the critical decisions made by the directors. Capital structure decision, capitalization, contributed capital and leverage proportion, all have a similar significance on the firm's performance. Therefore, financial issues due to CS not only affect the performance of a company but also powerfully impact macroeconomic results. As specified already, for both managers and suppliers of credit the capital structure is of most extreme significance.

Capital structure gets significance because it is emphatically identifies with the capacity of organizations to satisfy the requirements of different partners. Corporate finance literature has documented contradictory results regarding the influence of capital structure on firm performance. Capital structure related theories demonstrate a positive link between capital structure and firm performance whereas some studies also show negative results regarding the relationship. Particularly, Berger and Di Patti (2006); Gill et al (2011); Margaritis and Psillaki (2010) find that higher leverage ratio is linked with greater performance because higher debt ratio lessens the agency cost and inspires management to work in shareholders' interests.

However, Antoniou et al (2008); Zeitun and Tian (2014) indicate that leverage and firm value are negatively linked. Additionally, Vithessonthi and Tongu- 
rai (2015) investigate the association between leverage and FP in Thailand and find that firm performance is negatively affected by financial leverage. However, they further show the relationship is negative in the case of local firms whereas positive for global firms. Additionally, the size of the firm moderates the relationship because global companies have excessive assets, experience and ability to perform operations efficiently rather than local firms. On the contrary, Connelly et al (2012) in his study reported no association between leverage and FP and states that by taking more debts firms may get in the control of creditors and they monitor the firms more effectively. So, highly leveraged firms perform better than low leveraged firms due to strict monitoring activities.

\subsubsection{Corporate governance and capital structure}

The term "Corporate governance" comprises of a set of procedures that create an atmosphere of accountability, and transparency. It is used as a tool to reduce agency conflicts which in turn can influence the capital structure of a firm. It was found that financing decisions are not only affected by a firm's unique characteristics, but also by agency issues (Chang et al 2014). Liao, Mukherjee, and Wang (2015) examine that both higher leverage and rapid leverage adjustment towards the desired level are related with the best quality of governance. The detailed discussion is given below:

a) Institutional and insider shareholdings and leverage

Institutional theorists argue that the environment of organizations powerfully affects the growth of formal buildings of organizations. Agency theory states that whenever the shares of managers increase, it leads to entrenchment effects (Shleifer and Vishny 1997) and then converts a traditional issue of principalagent into the issue of principals with different objectives at the cost of minority investors. Agrawal and Knoeber (1996); Donaldson and Davis (1991) indicate that institutional, insider shareholdings and FP are positively related.

b) Board size and leverage

The size of the board plays an important role for the mechanism of corporate governance for controlling the operations of a business. The theory of "Resource dependency" postulates that greater size of the board improves FP due to different skills, information, and know-how. Chancharat et al (2012) indicate that a larger board size reduces the chances of insolvency. It is suggested that an appropriate board size consists of 5-12 directors. Berger et al (1997) indicate a negative effect while Jensen (1986) shows a positive relationship. So, it is considered that firms having larger boards perform better than others.

c) Duality and leverage

It is contended that higher agency costs and conflict arise whenever one individual holds both chairman and CEO positions (Ehikioya 2009). If both the positions are held by the same individual, agency cost can be increased (Dey et al 2011). CEO duality would increase the power of the chief executive over the board. It ultimately reduces the effectiveness of the governance structure and will lead to worst leverage. On the contrary, CEO's risk aversion lowers the financial leverage for firms having duality than non-dual firms.

d) The size of the audit committee and leverage 


\section{Z. Bashir et. al}

The Audit committee works under the direct control and supervision of the board of directors. It acts independently in preparing reports and accurately discloses all the necessary information. It is contended that the adequacy of the review board empowers the firms to easily access external financing, whenever required. However, the link can be positive or negative, contingent upon the underlying level of debt. The audited accounts of the company are a plus point for the company because financial institutions rely on audited accounts, so the firm can get the loans on favorable conditions. Then again, it might bring down the company's leverage if it perceives that debt ratio is too high. Apart from these, leverage depends upon other variables as well (Chen et al 2016). Connelly et al (2012) reveal that the audited statements of the firm enhance investors' and financial institution's confidence towards capital provision to the business. It is often argued that the audit committee's effectiveness can enable a business to have better access to external funding, when required.

e) Board independence and leverage

Independent executives are not the real investors and administrators of the organization. They should have suitable capability for the particular organizational activities, knowledge and experience as per criteria endorsed by the leading group of executives. The affinity of autonomous executives is relied upon to prompt higher leverage Berger et al (1997). As per literature, the affiliation of board independence and financial leverage is expected to be optimistic. Detthamrong et al (2017); Okiro (2015) also show a positive relationship between the independence of board and leverage.

f) Top-20 shareholders and leverage

Prior literature regarding block holders' ownership and leverage is indecisive. Shleifer and Vishny (1997) strongly support the supervisory part of block holders in restraining administrators' misbehaviors since they have a substantial concern with the organizations. In the meantime, Jensen (1986) recommends that obligations can be a viable organization system by submitting firms' assets to settled installments. If block shareholding and debt assume a comparative part in diminishing organization issues, though debt could be costly due to bankruptcy costs, it is anticipated that block holding is an alternate to debt. Myers and Majluf (1984) further state that block holders can easily get information regarding organizations' issues. In this way, it diminishes the data asymmetry issue between the firm and these financial specialists. In short, both data asymmetry and organization models anticipate a negative connection between block-holders and financial leverage (Lerner et al 2003; Sias 2004).

\subsubsection{Corporate governance, capital structure and firm performance}

Jensen and Meckling (1976) differentiate between internal and external equity, by showing the relationship between ownership and capital structure. Advancement in the agency theory proposes that both corporate governance and financing decisions impact firm value (Putnam et al 1994). It is critical to consider capital structure as a tool that can intervene and direct governance structure inside the organization and, thus, firm performance (Coase 1991).

Here in the last step it is assumed that corporate governance may not affect 
firm performance directly but effects indirectly. There might be the following possible reasons for this assumption. Firstly, badly governed firms may result in under or over debt financing. Firms with a higher leverage ratio have more variations in performance whereas lower leveraged firms tend to have small variations in performance. The second reason could be the board of directors evaluation and approval of the firm's decisions. If the chief executive is more risk averse and has a strong effect on the board, the organization may invest in less risky projects, which are possibly financed by equity financing, that may generate low returns.

\subsection{Critical review and recent developments}

The conception of corporate governance may be stated as an assortment of productive and worthwhile supervision that directs managerial decisions and aids to enhance the organization's performance. Al-Malkawi et al (2012) state that it performs control activities that provide owners with their required information and holds management responsible for their actions. Capital structure decision is an important decision taken by the management. An entity's capital structure means that how an organization is funded by a variety of equity and debt resources. Likewise, studies analyzed in the similar domain by Berger and Di Patti (2006); Gill et al (2011); Margaritis and Psillaki (2010), established that greater proportion of leverage is concomitant with better performance because higher debt ratio lessens the agency cost and inspires management to work for shareholders' benefit.

However, Antoniou et al (2008); Zeitun and Tian (2014), indicated that leverage and firm value are negative linked. Additionally, Vithessonthi and Tongurai (2015), investigated the association of leverage and FP in Thailand and discovered that firm performance was adversely influenced by financial leverage. It was found that financing decisions are not only affected due to the firm's unique characteristics, but also due to agency issues (Chang et al 2014). Similarly, Liao, Mukherjee, and Wang (2015), examined that both higher leverage and rapid leverage adjustment towards the desired level are related with the best quality of governance. Jensen and Meckling (1976) differentiated between internal and external equity, by showing the affiliation of ownership to capital structure.

Advancement in the agency theory proposes that both corporate governance and financing decisions impact firm value (Putnam et al 1994). It is precarious to contemplate that a portion of capital structure can be used as a tool that can intervene and direct the governance structure inside the organization and, thus, firm performance (Coase 1991). Finally, it is anticipated that an indirect intervention may exist for dynamic characteristics of corporate governance with different indicators of performance for an entity. The following could be the possible reasons for this assumption. Firstly, badly governed firms may result in under or over debt financing. Firms with a higher leverage ratio have more variations in performance whereas lower leveraged firms tend to have small variations in performance. The second reason could be the director of the corporate 


\section{Z. Bashir et. al}

board and his evaluation and approval for the firm's decisions. If the entity's CEO has a risk-averse tendency, and has the capability to influence the members of the corporate board, the organization may invest in less risky schemes, with the possibility of financing by equity resources, that may generate low returns as per the suggestions of (Ahmad and Mahmood 2015; Akhtar et al 2019; Alaaraj and Aoun 2016; Iqbal et al 2018; Khan et al 2019; Nuhu and Hussani 2017; Shahid et al 2016).

\subsection{Conceptual framework}

In the light of previous literature and the objectives of this research examination, the subsequent conceptual framework is established as figure 1 .

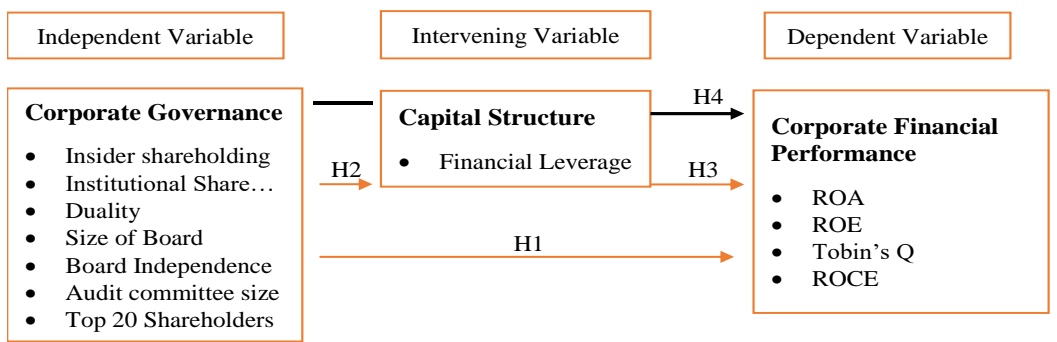

Fig. 1: Conceptual framework

\subsection{Research hypothesis}

In line with the literature evidence and the specific motives of the study, the following hypotheses have been tested using econometric and statistical procedures:

H1.1. Financial performance is positively linked with institutional shareholding H1.2: Financial performance is positively linked with insider shareholding

H1.3. Board size and financial performance are negatively linked

H1.4. Financial performance is inversely linked with CEO duality

H1.5. Financial performance is inversely linked with the size of the audit committee

H1.6. Top-20 shareholders and financial performance are positively linked

H1.7. Financial performance is positively linked with board independence $\mathrm{H} 2.1+2.2$. Institutional \& insider shareholding and financial leverage are positively related

H2.3. Financial leverage (CS) is positively linked with board size

H2.4. CEO Duality negatively affects financial leverage

H2.5. Financial leverage (CS) is positively linked with the size of the audit committee

H2.6. Board independence is positively linked with financial leverage 
H2.7. Financial leverage (CS) is positively linked with top-20 shareholdings

H3.1. Financial performance is positively linked with financial leverage

H4.1. Capital structure does not have the capacity to intermediate between the dynamic characteristics of corporate governance and different measures of financial performance.

\section{Research methodology}

\subsection{Sources and data collection}

This research uses PSX listed non-financial business entities as the population with manufacturing, food, chemicals, cement, automobiles and other industries. A sample of 113 business entities was selected randomly as per the data availability requirement on purposive basis. The study uses financial statement data collected over six years from 2013 to 2018 from financial statements as well from PSX website.

\subsection{Estimation requirements}

This research required panel estimation techniques to achieve the research objectives. The fixed effects or random effects were used to control absent timeinvariant characteristics of the firm, as well as fixed-effects of time, were used for controlling any ignored time-variant effect. Additionally, Baron and Kenny (1986) four-step procedure were used for testing the intervening effect.

\subsection{Model specification}

The econometric model was framed by considering the research objectives and nature of collected data. Firstly, to approximate the direct nexus of the dynamic characteristics of corporate governance with different indicators of performance of PSX listed non-financial firms, the following econometric model was established;

$$
(F P)_{i t}=\alpha+\alpha_{1}(C G)_{i, t}+\alpha_{2}(C V)_{i, t}+\left(\eta_{i}+\nu_{T i}\right)+\epsilon_{i t}
$$

where; FP denotes different financial indicators of performance like return on assets (ROA), return on equity (ROE) and return on capital employed (ROCE), as the book measures while Tobin's Q, as the market measure. The measure of the Corporate governance was used for all corporate governance related variables and CV is used for all controlled variables. $\eta_{i}$ denotes the firm's fixed-effect included in the panel estimation model for controlling the ignored firm-specific as well as time-invariant heterogeneity and, $\nu_{T}$ is the time-fixed effect in the panel estimation of the regression model for controlling ignored time-variants.

Secondly, to evaluate the direct nexus of the dynamic characteristics of corporate governance with the capital structure of PSX listed non-financial firms, following econometric panel estimation model was established;

$$
(C S)_{i t}=\alpha_{0}+\alpha_{1}(C G)_{i, t}+\alpha_{2}(C V)_{i, t}+\left(\eta_{i}+\nu_{t}\right)+\epsilon_{i t}
$$

Business Review: (2020) 15(1):108-133 


\section{Z. Bashir et. al}

where; CS denotes the Capital Structure by way of outcome variable and other things are same as discussed above. Thirdly, to assess the direct nexus of capital structure with different performance indicators of PSX listed non-financial firms, the following panel estimation regression model was established;

$$
(F P)_{i t}=\alpha_{0}+\alpha_{1}(C S)_{i, t}+\alpha_{2}(C V)_{i, t}+\left(\eta_{i}+\nu_{T i}\right)+\epsilon_{i t}
$$

Finally, to measure the intervening effect when treating FP as dependent and both corporate governance and CS as independent variables, the following panel estimation econometric model was established;

$$
(F P)_{i t}=\alpha_{0}+\alpha_{1}(C G)_{i, t}+\alpha_{2}(C S)_{i, t}+\alpha_{2}(C V)_{i, t}+\left(\eta_{i}+\nu_{T i}\right)+\epsilon_{i t}
$$

\subsection{Variables of the research}

"Financial Performance" was used as major outcome variable in the present research for testing the required hypotheses. Additionally, the study intends to use the dynamic characteristics of corporate governance as the major input variable and capital structure as an intermediary variable. Apart from this, some control variables were also used for controlling firm-specific features which can influence firm performance and financial leverage. The control variables include liquidity, entity's size, entity's age, market-to-book ratio, cash ratio, and tangibility ratio.

\subsubsection{Dependent variables}

"Financial Performance" is used as the dependent variable in the present research to test the required hypotheses. Three accounting and one market-based proxies were used. The accounting based proxies are 'ROA', 'ROE' and 'ROCE' while market based proxy is 'Tobin's Q' which are used to measure the firm's financial performance. ROA is the proportion of net earnings to totals assets. $\mathrm{ROE}$ is computed as the proportion of net earnings to total equity. Tobin's $\mathrm{Q}$ forecasts intangible worth of resources of a business such as goodwill, patents and growth opportunities (Ghazali 2010). Tobin's Q is computed as the sum of market size and total assets minus total equity divided by total assets. ROCE is the difference of EBIT and income from external outlay divided by the sum of share capital, debt, reserve less external investment.

\subsubsection{Independent variables}

This paper uses corporate governance as an independent variable and capital structure as an intervening variable. Corporate governance is analyzed through insider and institutional shareholdings, top twenty shareholders, board size and independence, audit committee size and duality. In addition to this, financial leverage is treated as the proxy of capital structure. The operational definitions of all these are given in table-1. 


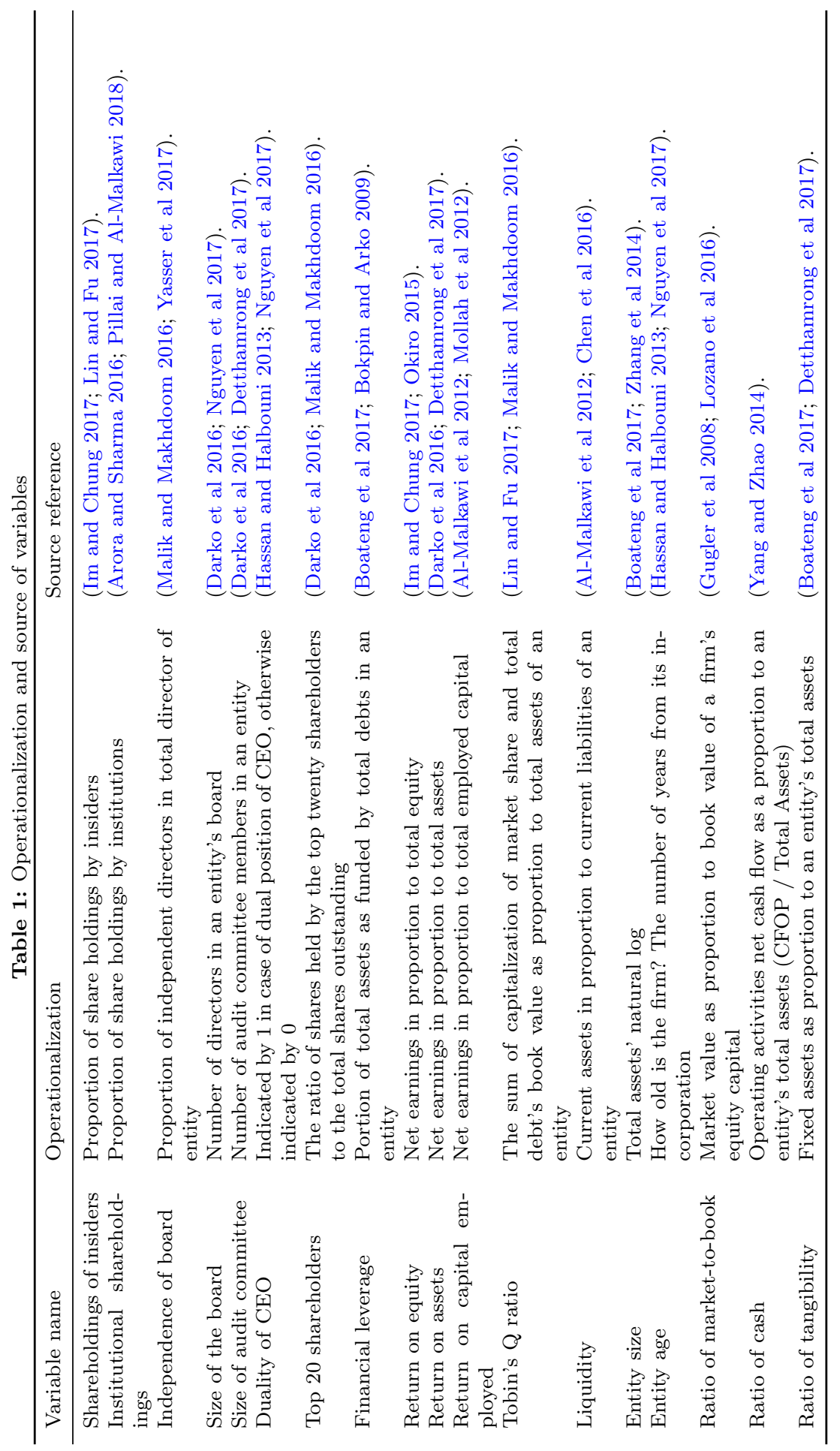

Business Review: (2020) 15(1):108-133 


\subsubsection{Control variables}

Apart from the explanatory, predicting and intervening variable, several control variables have been used to control firm-specific features which can influence firm performance and financial leverage. These include liquidity, firm size, firm age, market-to-book ratio, cash ratio, and tangibility ratio (see table-1 for operational definitions).

\section{Data analysis and discussion}

\subsection{Descriptive statistics}

Table 2 provides the descriptive statistics of sampled firms. The sample consists of 678 firms' observations covering six years from 2013-18. The table shows that average firm performance is $8.9 \%$ with a minimum of 0 and maximum of $124 \%$ in case of return on assets, $21.9 \%$ under the head of return on equity fluctuating from 0 to 4.30. Similarly, $158 \%$ in the case of Tobin's Q and $22.3 \%$ under return on capital employed is the average performance of sample firms. It can be seen that the firms are doing better in terms of market-based measures of performance. In addition to this, on average there exist 8 directors on the board and the mean age of the firms is 38 years with a minimum of 1 and a maximum of 149 years.

Table 2: Descriptive statistics

\begin{tabular}{lcccccc}
\hline Variable & Obs. & Mean & Median & Max & Min & Std. Dev. \\
\hline ROA & 678 & 0.088 & 0.057 & 1.241 & 0 & 0.113 \\
ROE & 678 & 0.219 & 0.138 & 4.302 & 0 & 0.373 \\
Tobin' Q & 678 & 1.583 & 1.033 & 21.368 & 0.123 & 1.840 \\
ROCE & 678 & 0.223 & 0.169 & 5.870 & -0.348 & 0.326 \\
Insd_S & 678 & 24.561 & 14.893 & 98.430 & 0 & 25.968 \\
Inst_S & 678 & 2.202 & 0.602 & 29.280 & 0 & 3.953 \\
B_Ind & 678 & 0.426 & 0.429 & 0.875 & 0.091 & 0.208 \\
B_Size & 678 & 7.989 & 8 & 14 & 5 & 0.088 \\
Dual & 678 & 0.198 & 0 & 1 & 0 & 0.403 \\
Aud_Size & 678 & 3.395 & 3 & 6 & 3 & 0.203 \\
Top20 & 678 & 0.906 & 0.942 & 1 & 0.253 & 0.101 \\
Leverage & 678 & 0.567 & 0.524 & 5.2 & 0.002 & 0.384 \\
Liquidity & 678 & 2.686 & 1.164 & 179.921 & 0 & 10.539 \\
F_Age & 678 & 38.341 & 33 & 149 & 1 & 21.961 \\
F_Size & 678 & 15.158 & 15.214 & 18.269 & 10.008 & 1.432 \\
Mtb & 678 & 2.586 & 1.078 & 114.456 & 0.069 & 7.563 \\
C_Ratio & 678 & 0.120 & 0.081 & 2.742 & 0.000 & 0.160 \\
Tang_R & 678 & 0.492 & 0.487 & 4.153 & 0.000 & 0.320 \\
\hline
\end{tabular}




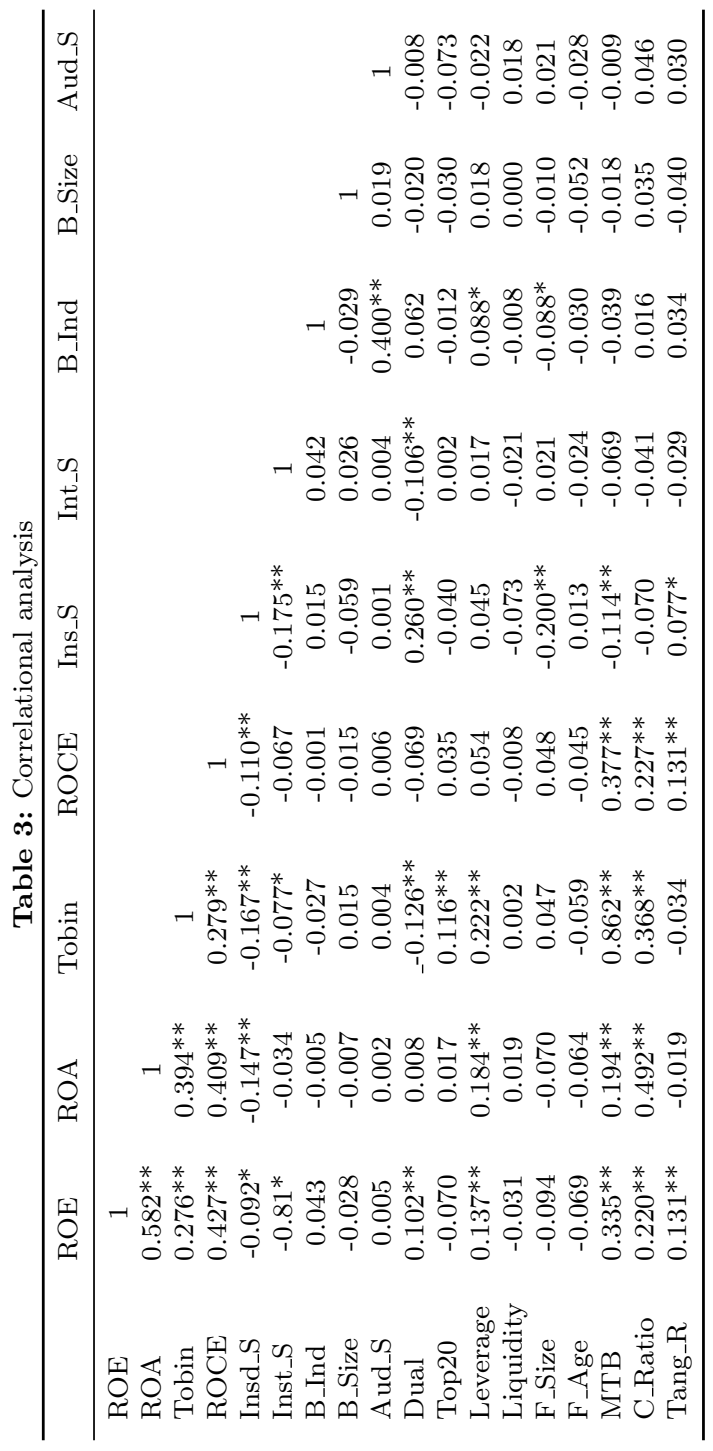

Business Review: (2020) 15(1):108-133 


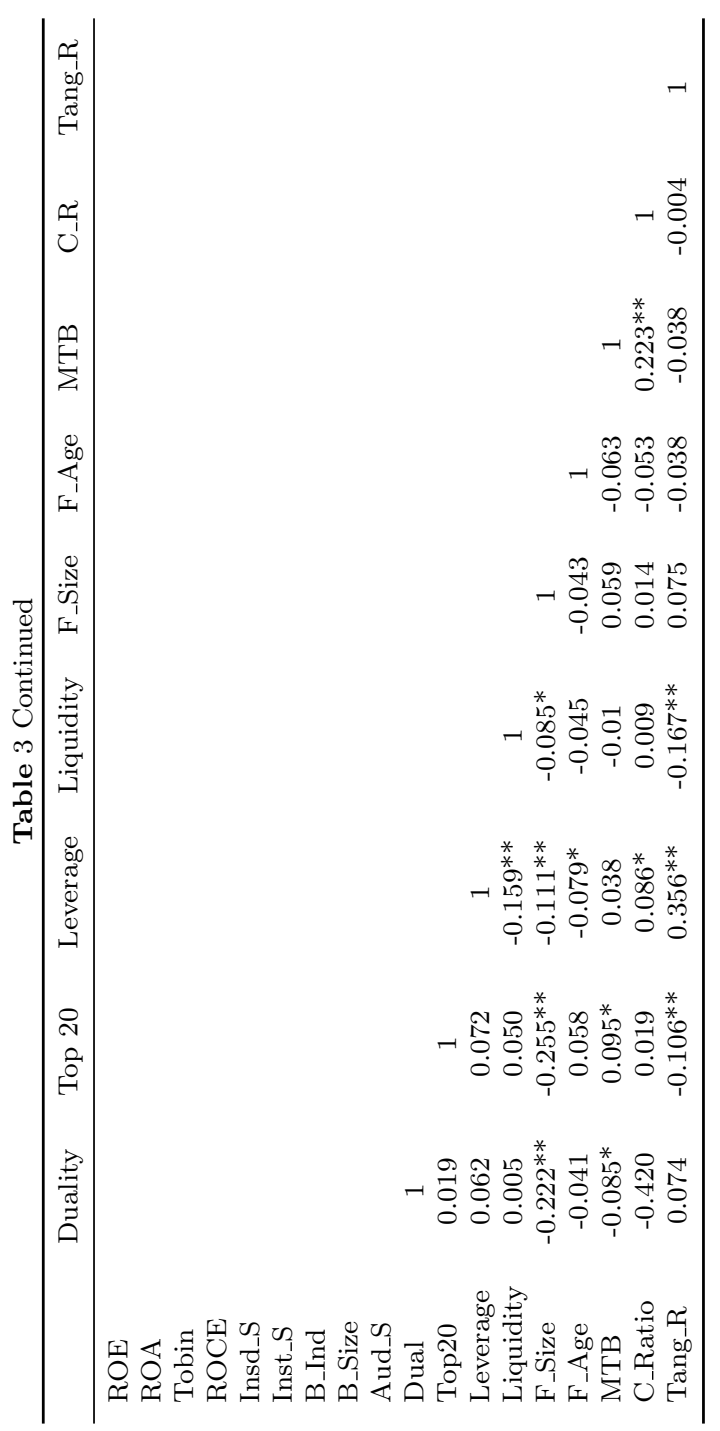




\subsection{Correlation analysis}

Table 3 represents the associations of all corporate governance, capital structure and financial performance variables. From table 3 all the FP proxies are positively associated with each other. All the corporate governance variables are positively correlated with return on equity instead of board size, insider and institutional shareholdings. Similarly, governance proxies are correlated with return on capital employed and Tobin's Q.

Table 3 shows that leverage is positively and significantly correlated with FP proxies instead of return on capital employed but the scale of correlation is fewer. Besides, the control variables like liquidity, firm's age and size are negative whereas market to book ratio, cash ratio and tangibility ratio are significantly $(\alpha=0.01)$ and positively associated with the return on equity.

\subsection{Dynamics of corporate governance and financial measures of performance}

In table 4 the return on equity, assets, Tobin's Q and return on capital employed are the dependent variables. About $54 \%$ of the variation in financial performance is explained by corporate governance under return on equity. Insider shareholding significantly but negatively affects ROE. Among control variables entity's age and other ratios like market to book, cash, and tangibility are positively and significantly related with return on equity.

In equation 3, Tobin's $\mathrm{Q}$ is positively influenced by all the governance variables other than insider, institution shareholding and duality. The negative coefficients show that the increase in insider and institution's percentage in the company harms the FP. This supports the notion "passive monitoring" which states that institutional investors are involved in short-term securities to get benefits based on symmetric information to fulfil their needs instead of enhancing firm's performance and the results are similar with (Duggal and Millar 1999; Elyasiani and Jia 2010).

\subsection{Capital structure and financial performance}

Table 5 shows the regression results regarding the impact of capital structure on financial performance. The r-square for capital structure as a variable describes $54 \%$ of the variation in return on equity while the remaining $46 \%$ is explained by other factors. The hypothesis that capital structure positively affects firm performance is accepted under ROE and ROCE and is not confirmed in the case of Tobin's Q and ROCE. In all the models, leverage positively and significantly affects ROA and Tobin's Q which shows that higher leverage ratio is linked with greater performance. These results are in line with the studies of (Berger and Di Patti 2006; Gill et al 2011; Margaritis and Psillaki 2010).

Business Review: (2020) 15(1):108-133 
Z. Bashir et. al

Table 4: Corporate governance and financial performance

\begin{tabular}{lcccccccc}
\hline DVs & \multicolumn{2}{c}{ ROE } & \multicolumn{2}{c}{ ROA } & \multicolumn{2}{c}{ Tobin's Q } & \multicolumn{2}{c}{ ROCE } \\
\hline IVS & Coeff & t-stat & Coeff & t-stat & Coeff & t-stat & Coeff & t-stat \\
\hline C & 0.612 & 2.255 & 0.678 & 3.418 & 2.473 & 1.608 & 1.490 & 2.035 \\
Insd_S & -0.127 & $-3.38^{* * *}$ & -0.001 & -1.467 & -0.003 & -0.798 & -0.002 & -1.017 \\
Inst_S & -0.059 & $-1.66^{*}$ & -0.001 & -0.513 & -0.011 & -0.869 & -0.001 & -0.108 \\
B_Ind & 0.037 & 0.976 & 0.010 & 0.590 & 0.177 & 1.366 & 0.058 & 0.942 \\
B_Size & -0.027 & -0.758 & -0.074 & $-2.005^{*}$ & 0.292 & 1.022 & 0.010 & 0.077 \\
Duality & -0.013 & -0.345 & -0.029 & -1.696 & -0.143 & -1.094 & -0.024 & -0.380 \\
A_Size & 0.118 & $3.21^{* *}$ & -0.005 & -0.275 & 0.023 & 0.172 & 0.02 & 0.319 \\
Top20 & 0.019 & 0.523 & -0.053 & -0.721 & 0.215 & 0.374 & -0.077 & -0.283 \\
Liquid & -0.028 & -0.788 & 0.000 & -0.950 & 0.003 & 0.929 & 0.000 & -0.079 \\
F_Age & -0.119 & $-3.14^{* *}$ & 0.004 & 1.843 & 0.111 & $7.190^{* *}$ & -0.007 & -0.911 \\
F_Size & -0.040 & -1.141 & -0.039 & $-3.030^{* * *}$ & -0.417 & $-4.130^{* *}$ & -0.059 & -1.225 \\
Mtb & 0.303 & $8.340^{* *}$ & -0.001 & -0.935 & 0.161 & $36.900^{* *}$ & 0.005 & $2.570^{*}$ \\
C_R & 0.147 & $4.100^{* * *}$ & 0.223 & $10.010^{* * *}$ & 0.779 & $4.510^{* *}$ & 0.155 & 1.880 \\
Tang & 0.145 & $4.090^{* *}$ & -0.036 & $-2.275^{* *}$ & 0.474 & $3.870^{* *}$ & -0.149 & $-2.550^{* *}$ \\
$R^{2}$ & 0.539 & & 0.639 & & 0.918 & 0.410 \\
Adj. $R^{2}$ & 0.435 & \multicolumn{2}{c}{0.558} & 0.899 & 0.277 \\
F-Stat & $5.163^{* *}$ & \multicolumn{2}{c}{$7.839^{* * *}$} & $49.641^{* * *}$ & $3.071^{* * *}$ \\
\hline
\end{tabular}

Table 5: Capital structure and financial performance

\begin{tabular}{lcccccccc}
\hline DVs & \multicolumn{2}{c}{ ROE } & \multicolumn{2}{c}{ ROA } & \multicolumn{2}{c}{ Tobin's Q } & \multicolumn{2}{c}{ ROCE } \\
\hline IVs & Coeff & t-stat & Coeff & t-stat & Coeff & t-stat & Coeff & t-stat \\
\hline C & 0.239 & 0.346 & -0.027 & -0.153 & -3.021 & -2.405 & 0.988 & 1.451 \\
Lev & 0.041 & 0.756 & 0.107 & $7.690^{* * *}$ & 1.291 & $13.12^{* * *}$ & 0.071 & 1.340 \\
Liquid & 0.000 & -0.101 & 0.005 & -0.394 & 0.006 & $2.200^{* *}$ & 0.000 & 0.024 \\
F_Size & -0.047 & -0.926 & -0.008 & -0.605 & -0.078 & -0.856 & -0.035 & -0.710 \\
F_Age & 0.014 & 1.858 & 0.005 & $2.620^{* * *}$ & 0.119 & $9.020^{* * *}$ & -0.006 & -0.800 \\
Mtb & 0.008 & $3.700^{* * *}$ & 0.002 & -0.603 & 0.163 & $42.720^{* * *}$ & 0.005 & $2.639^{* * *}$ \\
C_R & 0.308 & $3.710^{* * *}$ & 0.216 & $10.170^{* * *}$ & 0.700 & $4.640^{* * *}$ & 0.154 & $1.889^{*}$ \\
Tang & 0.177 & $2.800^{* *}$ & -0.081 & $-4.980^{* * *}$ & -0.076 & -0.661 & -0.175 & $-2.807^{* * *}$ \\
$R^{2}$ & 0.536 & & 0.668 & & 0.937 & 0.409 \\
Adj. $R^{2}$ & 0.437 & & 0.597 & 0.923 & 0.283 \\
F-Stat & $5.421^{* *}$ & \multicolumn{2}{c}{$9.432^{* * *}$} & & $69.641^{* * *}$ & & $3.246^{* *}$ \\
\hline
\end{tabular}

\subsection{Corporate governance and capital structure}

Table 6 shows that all the variables positively influence leverage except for duality and (aud_size). (Insd_S) positively and significantly affects leverage which implies that an increase in insider and institutional shareholding favours higher leverage ratio. In addition to this, (B_Ind) and (B_size) also positively influence financial leverage. The relationship between board independence and financial leverage is positive. The outcomes are similar with (Berger et al 1997; Boateng et al 2017), which state that independent executives with significant and valuable relations may assist the company to take advantage of outside financing sources. Furthermore, more independent executives on board and larger boards tend to result in a higher debt to equity ratio as indicated by (Berger and Di Patti 2006). 
Corporate governance and capital structure...

Table 6: Corporate governance and capital structure

\begin{tabular}{lcc}
\hline Variables & \multicolumn{2}{c}{ Leverage } \\
\hline & Coeff & t-stat \\
\hline C & 3.733 & 6.537 \\
Insd_S & 0.004 & $2.975^{* * *}$ \\
Inst_S & 0.005 & 1.148 \\
B_Ind & 0.089 & $1.852^{*}$ \\
B_Size & 0.057 & 0.539 \\
Duality & -0.056 & -1.154 \\
A_Size & -0.001 & -0.012 \\
Top20 & 0.334 & 1.572 \\
Liquidity & -0.002 & $-2.260^{*}$ \\
F_Age & -0.249 & $-6.639^{* * *}$ \\
F_Size & -0.003 & -0.444 \\
Mtb & -0.001 & -0.832 \\
C_R & 0.064 & 0.997 \\
Tang & 0.435 & $9.574^{* * *}$ \\
$R^{2}$ & \multicolumn{2}{c}{0.742} \\
Adjusted $R^{2}$ & \multicolumn{2}{c}{0.684} \\
F-statistic & \multicolumn{2}{c}{$12.700^{* * *}$} \\
\hline
\end{tabular}

4.6 Corporate governance, capital structure and financial performance

Table 7a-Intervening effect of leverage on the relationship between corporate governance and financial performance (ROE)

\begin{tabular}{lcccccccc}
\hline DVs & \multicolumn{2}{c}{$\mathrm{ROE}(1)$} & \multicolumn{2}{c}{ LEV $(2)$} & \multicolumn{2}{c}{$\mathrm{ROE}(3)$} & \multicolumn{2}{c}{$\mathrm{ROE}(4)$} \\
\hline Ivs & Coeff & t-stat & Coeff & t-stat & Coeff & t-stat & Coeff & t-stat \\
\hline C & 0.612 & 2.255 & 3.733 & 6.537 & 0.239 & 0.346 & 0.394 & 0.512 \\
Insd_S & -0.127 & $-3.377^{* * *}$ & 0.004 & $2.975^{* * *}$ & & & 0.000 & -1.068 \\
Inst_S & -0.059 & $-1.659^{*}$ & 0.005 & 1.148 & & & 0.000 & 0.032 \\
B_Ind & 0.037 & 0.976 & 0.089 & $1.852^{*}$ & & & 0.083 & 1.329 \\
B_Size & -0.027 & -0.758 & 0.057 & 0.539 & & & -0.110 & -0.782 \\
Duality & -0.013 & -0.345 & -0.056 & -1.154 & & & 0.007 & 0.104 \\
A_Size & 0.120 & $3.210^{* *}$ & -0.001 & -0.012 & & & 0.000 & -0.05 \\
Top20 & 0.019 & 0.523 & 0.334 & 1.572 & & & 0.026 & 0.094 \\
Leverage & & & & & 0.041 & 0.756 & 0.043 & 0.774 \\
Liquidity & -0.028 & -0.788 & -0.002 & $-2.260^{*}$ & 0 & -0.101 & 0.000 & -0.078 \\
F_Age & -0.119 & $-3.134^{* *}$ & -0.249 & $-6.639^{* * *}$ & -0.047 & -0.926 & 0.013 & $1.801^{*}$ \\
F_Size & -0.04 & -1.141 & -0.003 & -0.444 & 0.014 & 1.858 & -0.05 & -1.001 \\
Mtb & 0.303 & $8.34^{* * *}$ & -0.001 & -0.832 & 0.008 & $3.70^{* * *}$ & 0.008 & $3.654^{* * *}$ \\
C_R & 0.147 & $4.100^{* * *}$ & 0.064 & 0.997 & 0.308 & $3.710^{* * *}$ & 0.308 & $3.684^{* * *}$ \\
Tang & 0.145 & $4.068^{* * *}$ & 0.435 & $9.574^{* * *}$ & 0.177 & $2.798^{* * *}$ & 0.173 & $2.722^{* * *}$ \\
$R^{2}$ & \multicolumn{2}{c}{0.539} & 0.742 & & 0.536 & 0.539 \\
Adj. $R^{2}$ & \multicolumn{2}{c}{0.435} & \multicolumn{2}{c}{0.684} & 0.437 & 0.434 \\
F-Stat & $5.163^{* * *}$ & \multicolumn{2}{c}{$12.700^{* * *}$} & $5.421^{* * *}$ & $5.124^{* * *}$ \\
\hline
\end{tabular}

Table 7a through $7 \mathrm{~d}$ represents the results regarding the fourth hypothesis, which assumes that capital structure intervenes the effect of corporate governance on financial performance. For this it is necessary to analyze the regression results from equation one to equation four. To check either mediation holds,

Business Review: (2020) 15(1):108-133 
Z. Bashir et. al

Table $\mathbf{7 b}$-Intervening effect of leverage on the relationship between corporate governance and financial performance (ROA)

\begin{tabular}{|c|c|c|c|c|c|c|c|c|}
\hline DVs & \multicolumn{2}{|c|}{$\operatorname{ROA}(1)$} & \multicolumn{2}{|c|}{$\operatorname{LEV}(2)$} & \multicolumn{2}{|c|}{$\mathrm{ROA}(3)$} & \multicolumn{2}{|c|}{$\operatorname{ROA}(4)$} \\
\hline Ivs & Coeff & t-stat & Coeff & t-stat & Coeff & t-stat & Coeff & t-stat \\
\hline $\mathrm{C}$ & 0.678 & 3.418 & 3.733 & 6.537 & -0.027 & -0.150 & 0.254 & 1.305 \\
\hline Insd_S & -0.001 & -1.467 & 0.004 & $2.975 * * *$ & & & -0.001 & $-2.558^{* *}$ \\
\hline Inst_S & -0.001 & -0.513 & 0.005 & 1.148 & & & -0.001 & -0.938 \\
\hline B_Ind & 0.010 & 0.590 & 0.089 & $1.852^{*}$ & & & 0 & -0.016 \\
\hline B_Size & -0.074 & $-2.005^{*}$ & 0.057 & 0.539 & & & -0.08 & $-2.305^{* *}$ \\
\hline Duality & -0.029 & -1.696 & -0.056 & -1.154 & & & -0.022 & -1.393 \\
\hline A_Size & -0.005 & -0.275 & -0.001 & -0.012 & & & -0.005 & -0.287 \\
\hline Top20 & -0.053 & -0.721 & 0.334 & 1.572 & & & -0.091 & -1.303 \\
\hline Leverage & & & & & 0.107 & $7.692^{* * *}$ & 0.114 & $8.116^{* * *}$ \\
\hline Liquidity & 0.000 & -0.950 & -0.002 & $-2.260^{*}$ & 0.005 & -0.394 & 0.000 & -0.223 \\
\hline F_Age & 0.004 & 1.843 & -0.249 & $-6.639 * * *$ & -0.008 & -0.605 & 0.004 & $2.101^{* *}$ \\
\hline F_Size & -0.039 & $-3.031^{* *}$ & -0.003 & -0.444 & 0.005 & $2.624^{* * *}$ & -0.011 & -0.876 \\
\hline Mtb & -0.001 & -0.935 & -0.001 & -0.832 & 0.002 & -0.603 & 0.000 & -0.701 \\
\hline C_R & 0.223 & $10.010 * * *$ & 0.064 & 0.997 & 0.216 & $10.171^{* * *}$ & 0.216 & $10.228^{* * *}$ \\
\hline Tang & -0.036 & $-2.275^{* *}$ & 0.435 & $9.574^{* * *}$ & -0.081 & $-4.983^{* * *}$ & -0.085 & $-5.290 * * *$ \\
\hline$R^{2}$ & \multicolumn{2}{|c|}{0.639} & \multicolumn{2}{|c|}{0.742} & \multicolumn{2}{|c|}{0.668} & \multicolumn{2}{|c|}{0.678} \\
\hline Adj. $R^{2}$ & \multicolumn{2}{|c|}{0.558} & \multicolumn{2}{|c|}{0.684} & \multicolumn{2}{|c|}{0.597} & \multicolumn{2}{|c|}{0.605} \\
\hline F-Stat & \multicolumn{2}{|c|}{7.839} & \multicolumn{2}{|c|}{$12.700 * * *$} & \multicolumn{2}{|c|}{9.432} & \multicolumn{2}{|c|}{$9.214^{* * *}$} \\
\hline
\end{tabular}

Table 7c-Intervening effect of leverage on the relationship between corporate governance and financial performance (Tobin's Q)

\begin{tabular}{|c|c|c|c|c|c|c|c|c|}
\hline \multirow{2}{*}{$\frac{\text { DVs }}{\text { Ivs }}$} & \multicolumn{2}{|c|}{ Tobin's Q (1) } & \multicolumn{2}{|c|}{ LEV (2) } & \multicolumn{2}{|c|}{ Tobin's Q (3) } & \multicolumn{2}{|c|}{ Tobin's Q (4) } \\
\hline & Coeff & t-stat & Coeff & t-stat & Coeff & t-stat & Coeff & t-stat \\
\hline $\mathrm{C}$ & 2.473 & 1.608 & 3.733 & 6.537 & -3.021 & -2.405 & -2.475 & -1.779 \\
\hline Insd_S & -0.003 & -0.798 & 0.004 & $2.975^{* *}$ & & & -0.008 & $-2.576^{* *}$ \\
\hline Inst_S & -0.011 & -0.869 & 0.005 & 1.148 & & & -0.018 & -1.643 \\
\hline B_Ind & 0.177 & 1.366 & 0.089 & $1.852^{*}$ & & & 0.059 & 0.520 \\
\hline B_Size & 0.292 & 1.022 & 0.057 & 0.539 & & & 0.216 & 0.868 \\
\hline Duality & -0.143 & -1.094 & -0.056 & -1.154 & & & -0.069 & -0.603 \\
\hline A_Size & 0.023 & 0.172 & -0.001 & -0.012 & & & 0.023 & 0.204 \\
\hline Top20 & 0.215 & 0.374 & 0.334 & 1.572 & & & -0.229 & -0.457 \\
\hline Lev & & & & & 1.291 & $13.120^{* * *}$ & 1.326 & $13.270^{* * *}$ \\
\hline Liquid & 0.003 & 0.929 & -0.002 & $-2.260^{*}$ & 0.006 & $2.199 * *$ & 0.006 & $2.332^{* *}$ \\
\hline F_Age & 0.111 & $7.194^{* *}$ & -0.249 & $-6.640 * * *$ & -0.078 & -0.856 & 0.114 & $8.507 * * *$ \\
\hline F_Size & -0.417 & $-4.130 * *$ & -0.003 & -0.444 & 0.119 & $9.017^{* * *}$ & -0.087 & -0.950 \\
\hline Mtb & 0.161 & $36.900 * *$ & -0.001 & -0.832 & 0.163 & $42.73^{* * *}$ & 0.163 & $42.790 * * *$ \\
\hline C_R & 0.779 & $4.510 * * *$ & 0.064 & 0.997 & 0.700 & $4.644^{* * *}$ & 0.694 & $4.605^{* * *}$ \\
\hline Tang & 0.474 & $3.872^{* *}$ & 0.435 & $9.570 * * *$ & -0.076 & -0.661 & -0.103 & -0.893 \\
\hline$R^{2}$ & \multicolumn{2}{|c|}{0.918} & \multicolumn{2}{|c|}{0.742} & \multicolumn{2}{|c|}{0.937} & \multicolumn{2}{|c|}{0.938} \\
\hline Adj. $R^{2}$ & \multicolumn{2}{|c|}{0.899} & \multicolumn{2}{|c|}{0.684} & \multicolumn{2}{|c|}{0.923} & \multicolumn{2}{|c|}{0.924} \\
\hline F-Stat & \multicolumn{2}{|c|}{49.641} & \multicolumn{2}{|c|}{$12.700 * * *$} & \multicolumn{2}{|c|}{69.642} & \multicolumn{2}{|c|}{$66.267^{* * *}$} \\
\hline
\end{tabular}

Baron and Kenny (1986) technique is used. For this purpose, the following conditions must be met: first the independent variable (CG) must influence the dependent variable $(\mathrm{FP})$. In the second stage the independent variable (corporate governance) significantly influences the intervening variable (capital structure). In the third step, the intervening variable (CS) also significantly affects the dependent variable (FP). In the end, the impact of the causal variable (corporate governance) on dependent (FP) variable by controlling the mediating (capital 
Corporate governance and capital structure...

Table $\mathbf{7 d}$-Intervening effect of leverage on the relationship between corporate governance and financial performance (ROCE)

\begin{tabular}{lcccccccc}
\hline DVs & \multicolumn{2}{c}{ ROCE $(1)$} & \multicolumn{2}{c}{ LEV $(2)$} & \multicolumn{2}{c}{ ROCE $(3)$} & \multicolumn{2}{c}{ ROCE $(4)$} \\
\hline Ivs & Coeff & t-stat & Coeff & t-stat & Coeff & t-stat & Coeff & t-stat \\
\hline C & 1.490 & 2.035 & 3.733 & 6.537 & 0.988 & 1.451 & 1.205 & 1.587 \\
Insd_S & -0.002 & -1.017 & 0.004 & $2.98^{* * *}$ & & & -0.002 & -1.186 \\
Inst_S & -0.001 & -0.108 & 0.005 & 1.148 & & & -0.001 & -0.176 \\
B_Ind & 0.058 & 0.942 & 0.089 & $1.852^{*}$ & & & 0.051 & 0.830 \\
B_Size & 0.01 & 0.077 & 0.057 & 0.539 & & & 0.006 & 0.044 \\
Duality & -0.024 & -0.380 & -0.056 & -1.154 & & & -0.019 & -0.311 \\
A_Size & 0.02 & 0.319 & -0.001 & -0.012 & & & 0.020 & 0.320 \\
Top20 & -0.077 & -0.283 & 0.334 & 1.572 & & & -0.103 & -0.376 \\
Leverage & & & & & 0.071 & 1.340 & 0.076 & 1.400 \\
Liquidity & 0.000 & -0.079 & -0.002 & $-2.260^{*}$ & 0.000 & 0.024 & 0.000 & 0.055 \\
F_Age & -0.007 & -0.911 & -0.249 & $-6.640^{* * *}$ & -0.035 & -0.710 & -0.006 & -0.886 \\
F_Size & -0.059 & -1.225 & -0.003 & -0.444 & -0.006 & -0.800 & -0.040 & -0.800 \\
Mtb & 0.005 & $2.565^{*}$ & -0.001 & -0.832 & 0.005 & $2.640^{* * *}$ & 0.005 & $2.615^{* * *}$ \\
C_R & 0.155 & 1.880 & 0.064 & 0.997 & 0.154 & $1.889^{*}$ & 0.150 & $1.821^{*}$ \\
Tang & -0.149 & $-2.550^{* *}$ & 0.435 & $9.570^{* * *}$ & -0.175 & $-2.810^{* * *}$ & -0.182 & $-2.900^{* * *}$ \\
$R^{2}$ & 0.410 & \multicolumn{2}{c}{0.742} & & 0.409 & 0.412 \\
Adj. $R^{2}$ & \multicolumn{2}{c}{0.277} & \multicolumn{2}{c}{0.684} & & 0.283 & 0.278 \\
F-Stat & \multicolumn{2}{c}{3.0714} & \multicolumn{2}{c}{$12.700^{* * *}$} & & 3.246 & $3.068^{* * *}$ \\
\hline
\end{tabular}

structure) variable is examined. Mediation occurs if the causal variable (CG) insignificantly affects the dependent variable (FP) (Baron and Kenny 1986). From the results reported in the table, leverage only intervenes in the relationship between tangibility and financial performance. In general, the outcomes do not support the fourth hypothesis and show that leverage, a proxy for capital structure does not intervene in the relationship between corporate governance and financial performance in case of non-financial registered companies in Pakistan.

\section{Conclusion and recommendations}

This study analyzed the intervention of capital structure with different characteristics of corporate governance and different measures of financial performance using Baron and Kenny (1986) four-step procedure on non- financial firms registered in the PSX. Panel data set of 113 non-financial listed firms covering six years from 2013-18 was used and analysis was performed using multiple regression techniques.

First, the impact of corporate governance on financial performance was investigated. The findings indicated that insider shareholding significantly but negatively whereas auditing committee size positively and significantly affect ROE. (Aud_Size) significantly affects financial performance which implies that larger audit committee increases financial performance. In the second step, the impact of corporate governance on the capital structure was examined. The results showed that (Insd_S) and (B_Ind) positively and significantly influence leverage. This means that firms with a higher ratio of independent executives on board uses more debts. Further, the negative effect of (aud_size) on leverage suggests that larger audit committees are more conservative as far as capi- 
tal structure decision is concerned, consequently prompting to lower leverage ratio. Thirdly, the impact of capital structure on financial performance was analyzed and the results indicated that capital structure measured by leverage has no relationship with financial performance in terms of ROE and ROCE. This indicates that high leverage ratio is linked with greater performance because higher debt ratio lessens the agency cost and inspires management to work for shareholders' benefit. Finally, the ultimate target was that how the inclusion of capital structure influences the relationship between corporate governance and financial performance. The findings did not support the hypotheses that capital structure does not intervene between corporate governance and financial performance. However, tangibility is the only factor that mediates the relationship.

The study only includes numerical variables such as insider and institutional shareholdings, top twenty shareholders and duality. The inclusion of qualitative values can further explain the relationship very well. One conceivable road for future investigation is to inspect external stakeholders' perceptions concerning corporate administration practices. Besides, it is suggested that future examinations particularly explore the executive meetings, board advisory group, CEO execution, CEO abilities, the tenure of the CEO, staff tenure and capabilities.

\section{References}

Agrawal A, Knoeber CR (1996) Firm performance and mechanisms to control agency problems between managers and shareholders. Journal of financial and quantitative analysis pp 377397

Ahmad Z, Mahmood Z (2015) Worldwide diffusion of corporate governance (cg) regulations and practices: A literature review. Journal of Accounting and Finance in Emerging Economies 1(1):55-68

Akhtar A, Bakhsh A, Ali M, Kousar S (2019) Impact of capital structure on the performance of textilesector in pakistan: Examining the moderating effect of liquidity. Journal of Accounting and Finance in Emerging Economies 5(1):1-12

Al-Malkawi HAN, Arabia S, Pillai R, Dhabi A, et al (2012) Internal mechanisms of corporate governance and firm performance: a review of theory and empirical evidence. Journal of Modern Accounting and Auditing 8(4):549

Al-Najjar B, Abed S (2014) The association between disclosure of forward-looking information and corporate governance mechanisms. Managerial Auditing Journal

Alaaraj H, Aoun M (2016) Financial performance indicators in lebanese hospitals: a sustainable improvement strategy. Journal of Accounting and Finance in Emerging Economies $2(2): 69-75$

Aldamen H, Duncan K, Kelly S, McNamara R, Nagel S (2012) Audit committee characteristics and firm performance during the global financial crisis. Accounting \& Finance 52(4):9711000

Antoniou A, Guney Y, Paudyal K (2008) The determinants of capital structure: capital market-oriented versus bank-oriented institutions. Journal of financial and quantitative analysis pp 59-92

Arora A, Sharma C (2016) Corporate governance and firm performance in developing countries: evidence from india. Corporate governance

Baliga BR, Moyer RC, Rao RS (1996) Ceo duality and firm performance: What's the fuss? Strategic management journal 17(1):41-53

Barnhart SW, Rosenstein S (1998) Board composition, managerial ownership, and firm performance: An empirical analysis. Financial Review 33(4):1-16

Baron RM, Kenny DA (1986) The moderator-mediator variable distinction in social psychological research: Conceptual, strategic, and statistical considerations. Journal of personality and social psychology 51(6):1173 
Becht M, Bolton P, Roell A (2002) Corporate governance and control', ecgifinance working paper no. 02/2002. Available form: http://unpan1 un org/intradoc/groups/public/documents/apcity/unpan033582 pdf

Berger AN, Di Patti EB (2006) Capital structure and firm performance: A new approach to testing agency theory and an application to the banking industry. Journal of Banking \& Finance 30(4):1065-1102

Berger PG, Ofek E, Yermack DL (1997) Managerial entrenchment and capital structure decisions. The journal of finance 52(4):1411-1438

Boateng A, Cai H, Borgia D, Bi XG, Ngwu FN (2017) The influence of internal corporate governance mechanisms on capital structure decisions of chinese listed firms. Review of Accounting and Finance

Bokpin GA, Arko AC (2009) Ownership structure, corporate governance and capital structure decisions of firms. Studies in Economics and Finance

Chancharat N, Krishnamurti C, Tian G (2012) Board structure and survival of new economy ipo firms. Corporate Governance: An International Review 20(2):144-163

Chang YK, Chou RK, Huang TH (2014) Corporate governance and the dynamics of capital structure: New evidence. Journal of Banking \& Finance 48:374-385

Chen PF, He S, Ma Z, Stice D (2016) The information role of audit opinions in debt contracting. Journal of Accounting and Economics 61(1):121-144

Coase R (1991) The institutional structure of production. Journal des économistes et des études humaines 2(4):431-440

Connelly JT, Limpaphayom P, Nagarajan NJ (2012) Form versus substance: The effect of ownership structure and corporate governance on firm value in thailand. Journal of Banking \& Finance 36(6):1722-1743

Dalton DR, Daily CM, Johnson JL, Ellstrand AE (1999) Number of directors and financial performance: A meta-analysis. Academy of Management journal 42(6):674-686

Darko J, Aribi ZA, Uzonwanne GC (2016) Corporate governance: the impact of director and board structure, ownership structure and corporate control on the performance of listed companies on the ghana stock exchange. Corporate Governance

Detthamrong U, Chancharat N, Vithessonthi C (2017) Corporate governance, capital structure and firm performance: Evidence from thailand. Research in International Business and Finance 42:689-709

Dey A, Engel E, Liu X (2011) Ceo and board chair roles: To split or not to split? Journal of Corporate Finance 17(5):1595-1618

Donaldson L, Davis JH (1991) Stewardship theory or agency theory: Ceo governance and shareholder returns. Australian Journal of management 16(1):49-64

Duggal R, Millar JA (1999) Institutional ownership and firm performance: The case of bidder returns. Journal of Corporate Finance 5(2):103-117

Ehikioya BI (2009) Corporate governance structure and firm performance in developing economies: evidence from nigeria. Corporate Governance: The international journal of business in society

El Mir A, Seboui S (2008) Corporate governance and the relationship between eva and created shareholder value. Corporate Governance: The international journal of business in society

Elsayed K (2007) Does ceo duality really affect corporate performance? Corporate governance: an international review 15(6):1203-1214

Elyasiani E, Jia J (2010) Distribution of institutional ownership and corporate firm performance. Journal of banking \& finance 34(3):606-620

Ezzamel M, Watson R (1993) Organizational form, ownership structure and corporate performance: A contextual empirical analysis of uk companies 1. British Journal of Management 4(3):161-176

Fan JP, Wei KJ, Xu X (2011) Corporate finance and governance in emerging markets: A selective review and an agenda for future research

Ghazali NAM (2010) Ownership structure, corporate governance and corporate performance in malaysia. International Journal of Commerce and Management

Gill A, Biger N, Mathur N (2011) The effect of capital structure on profitability: Evidence from the united states. International Journal of Management 28(4):3

Gu Z, Kim YK (2001) Managerial stock holdings and firm performance: empirical evidence from the restaurant industry. International journal of hospitality \& tourism administration $2(1): 49-65$

Business Review: (2020) 15(1):108-133 
Gugler K, Mueller DC, Yurtoglu BB (2008) Insider ownership, ownership concentration and investment performance: An international comparison. Journal of Corporate Finance 14(5):688-705

Guillet BD, Seo K, Kucukusta D, Lee S (2013) Ceo duality and firm performance in the us restaurant industry: Moderating role of restaurant type. International Journal of Hospitality Management 33:339-346

Haniffa R, Hudaib M (2006) Corporate governance structure and performance of malaysian listed companies. Journal of Business Finance \& Accounting 33(7-8):1034-1062

Hart SL (1995) A natural-resource-based view of the firm. Academy of management review 20(4):986-1014

Hassan MK, Halbouni SS (2013) Corporate governance, economic turbulence and financial performance of uae listed firms. Studies in Economics and Finance

Heugens PP, Van Essen M, van Oosterhout JH (2009) Meta-analyzing ownership concentration and firm performance in asia: Towards a more fine-grained understanding. Asia Pacific Journal of Management 26(3):481-512

Himmelberg CP, Hubbard RG, Palia D (1999) Understanding the determinants of managerial ownership and the link between ownership and performance. Journal of financial economics 53(3):353-384

Hiraki T, Inoue H, Ito A, Kuroki F, Masuda H (2003) Corporate governance and firm value in japan: Evidence from 1985 to 1998. Pacific-Basin Finance Journal 11(3):239-265

Hossain M, Prevost AK, Rao RP (2001) Corporate governance in new zealand: The effect of the 1993 companies act on the relation between board composition and firm performance. Pacific-Basin Finance Journal 9(2):119-145

Im J, Chung Y (2017) The effects of insider ownership and board composition on firm performance in the restaurant industry. The Journal of Hospitality Financial Management 25(1):4-16

Iqbal J, Sandhu MA, Ahmad Z, Javed MH, Ali W (2018) Impact of leverage and risk exposure on financial performance in smes of northern punjab. Journal of Accounting and Finance in Emerging Economies 4(1):17-28

Jensen MC (1986) Agency costs of free cash flow, corporate finance, and takeovers. The American economic review 76(2):323-329

Jensen MC, Meckling WH (1976) Theory of the firm: Managerial behavior, agency costs and ownership structure. Journal of financial economics 3(4):305-360

Joh SW, Jung JY (2012) The effects of outside board on firm value in the emerging market from the perspective of information transaction costs. Asia-Pacific Journal of Financial Studies 41(2):175-193

Keasey K, Wright M (1993) Issues in corporate accountability and governance: An editorial. Accounting and business research 23(sup1):291-303

Khan SN, Yaseen MN, Mustafa F, Abbasi S (2019) The interaction effect of financial leverage on the relationship between board attributes and firm performance; evidence of nonfinancial listed companies of pakistan. Journal of Accounting and Finance in Emerging Economies 5(1):115-122

Krause R, Semadeni M, Cannella Jr AA (2014) Ceo duality: A review and research agenda. Journal of Management 40(1):256-286

Lerner J, Shane H, Tsai A (2003) Do equity financing cycles matter? evidence from biotechnology alliances. Journal of Financial Economics 67(3):411-446

Letza S, Sun X, Kirkbride J (2004) Shareholding versus stakeholding: A critical review of corporate governance. Corporate Governance: An International Review 12(3):242-262

Lin YR, Fu XM (2017) Does institutional ownership influence firm performance? evidence from china. International Review of Economics \& Finance 49:17-57

Lozano MB, Martínez B, Pindado J (2016) Corporate governance, ownership and firm value: Drivers of ownership as a good corporate governance mechanism. International Business Review 25(6):1333-1343

Malik MS, Makhdoom DD (2016) Does corporate governance beget firm performance in fortune global 500 companies? Corporate Governance

Margaritis D, Psillaki M (2010) Capital structure, equity ownership and firm performance. Journal of banking \& finance 34(3):621-632

Maury B (2006) Family ownership and firm performance: Empirical evidence from western european corporations. Journal of corporate finance 12(2):321-341 
Mollah S, Al Farooque O, Karim W (2012) Ownership structure, corporate governance and firm performance. Studies in Economics and Finance

Myers SC, Majluf NS (1984) Corporate financing and investment decisions when firms have informationthat investors do not have. Tech. rep., National Bureau of Economic Research

Nguyen TTM, Evans E, Lu M (2017) Independent directors, ownership concentration and firm performance in listed companies. Pacific Accounting Review

Nuhu M, Hussani SM (2017) Empirical study of the relationship between board of director mechanisms and perceived performance of listed firms in nigeria. Journal of Accounting and Finance in Emerging Economies 3(2):159-178

Okiro KO (2015) The effect of corporate governanace and capital structure on performance of firms listed at the east african community securities exchange

Pearce JA, Zahra SA (1991) The relative power of ceos and boards of directors: Associations with corporate performance. Strategic management journal 12(2):135-153

Pfeffer J, Salancik G (1978) The external control of organizations: A resource dependence perspective

Pillai R, Al-Malkawi HAN (2018) On the relationship between corporate governance and firm performance: Evidence from gcc countries. Research in International Business and Finance 44:394-410

Putnam RD, Leonardi R, Nanetti RY (1994) Making democracy work: Civic traditions in modern Italy. Princeton university press

Rechner PL, Dalton DR (1991) Ceo duality and organizational performance: A longitudinal analysis. Strategic management journal 12(2):155-160

Shahid MS, Khakwani MS, Hamza A (2016) Effect of corporate governance and financial leverage on market value added in pakistan. Journal of Accounting and Finance in Emerging Economies 2(1):17-26

Shleifer A, Vishny RW (1997) A survey of corporate governance. The journal of finance $52(2): 737-783$

Sias RW (2004) Institutional herding. The Review of Financial Studies 17(1):165-206

Vithessonthi C, Tongurai J (2015) The effect of leverage on performance: Domesticallyoriented versus internationally-oriented firms. Research in International Business and Finance 34:265-280

Yang T, Zhao S (2014) Ceo duality and firm performance: Evidence from an exogenous shock to the competitive environment. Journal of Banking \& Finance 49:534-552

Yasser QR, Al Mamun A, Rodrigs M (2017) Impact of board structure on firm performance: evidence from an emerging economy. Journal of Asia Business Studies

Yeh CM, Trejos B (2015) The influence of governance on tourism firm performance. Current Issues in Tourism 18(4):299-314

Zeitun R, Tian GG (2014) Capital structure and corporate performance: evidence from jordan. Australasian Accounting Business \& Finance Journal, Forthcoming

Zhang Q, Chen L, Feng T (2014) Mediation or moderation? the role of r\&d investment in the relationship between corporate governance and firm performance: Empirical evidence from the chinese it industry. Corporate Governance: An International Review 22(6):501-517

Business Review: (2020) 15(1):108-133 